Author: S de Freitas \&

G Myburgh

SEEKING DELIBERATION ON THE UNBORN IN INTERNATIONAL LAW

2011 VOLUME 14 No 5

http://dx.doi.org/10.4314/pelj.v14i5.2 


\title{
SEEKING DELIBERATION ON THE UNBORN IN INTERNATIONAL LAW
}

\author{
SA de Freitas* \\ GA Myburgh ${ }^{\star *}$
}

\section{Introduction}

After World War II, international law moved away from being a matter simply of agreements and rules between states, and now involves the establishment of human rights and humanitarian requirements which serve as rules applicable to all states and are also applicable to the relationship between each state and its citizens. International human rights instruments and jurisprudence are popular and authoritative, reflecting an understanding of international law as serving the protection of the fundamental rights of the individual in the context of a universal sense of morality. The question of the legal status and protection of the unborn ${ }^{1}$ in international law is therefore implicated in this understanding of international law. At the basis of this understanding lies a concern for the protection of mankind, an issue which is inextricably linked to the question of the beginning of life, the parameters of human dignity, and to the essence of being human.

During the latter half of the $20^{\text {th }}$ century especially, the emphasis on universals in the form of the protection of fundamental human rights has introduced a moral measure into international law that transcends the purposes of peaceful existence, heralding an international legal system that exhibits a moral conscience inextricably linked to

Prof Shaun A de Freitas, B.Proc, LLB, LLM by thesis. Departmental Chairperson and Associate Professor, Department of Constitutional Law and Philosophy of Law, University of the Free State. Email: defreitas@ufs.ac.za.

** Ms Georgia A Myburgh. LLB, LLM by thesis. Assistant Researcher and Doctoral Fellow, Department of Constitutional Law and Philosophy of Law, University of the Free State. The authors are indebted to Robert $\mathrm{J}$ Araujo (Professor of Ethics and International Relations at the Pontifical Gregorian University, and advisor to the Holy See in Rome); lain T Benson (Senior Associate Counsel of the National Canadian Law firm Miller Thomson LLP and Extraordinary Professor at the Department of Constitutional Law and Philosophy of Law, University of the Free State); and Jeffery J Ventrella (Senior Vice-President of the Office of Strategic Training of the Alliance Defense Fund [ADF], Phoenix, USA) for their review and very helpful comments on earlier drafts.

In this article "unborn" refers to the "entity" formed at fertilisation and continuing until birth. The notion of "protection" is not necessarily included in "absolute protection". 
benevolence, humanity and humaneness. ${ }^{2}$ Wilfred Jenks observes that each of the founders of modern international law, Vitoria, Suarez and Grotius, proceeded in their several ways upon the hypothesis that:

The individual is the ultimate unit of all law, international and municipal, in the double sense that the obligations of international law are ultimately addressed to him or her and that the development, the well-being and the dignity of the individual human being are a matter of direct concern to international law. ${ }^{3}$

Human rights and "being human" are inextricably connected to each other. ${ }^{4}$ Referring to the fundamental and foundational international instruments such as the European Convention for the Protection of Human Rights and Fundamental Freedoms, 1950, and the International Covenant on Civil and Political Rights, 1966, Wilfred Jenks states that a legal system in which such rights increasingly hold a central place has evolved in the direction of a common law of mankind - it is no longer a law between states only and exclusively, but a law which embodies guarantees of individual rights which are simultaneously national and international in character and are enforced by both national and international procedures. ${ }^{5}$ Therefore, if the end of all law is the human being, if there is an inextricable relationship between human rights and "being human", and if it is critical for our understanding of international and human rights law to see how it can protect the individual, then it is also important to address the legal status of the unborn from an international law perspective.

2 According to Richard Wilkins and Jacob Reynolds, anti-abortion academicians may not have adequately understood the hopes and dreams of the men and women who created the UN system. The UN was founded to prevent the systematic disregard of fundamental principles; the world should be reminded of the dangers that inhere in disregarding the intrinsic dignity and inviolability of all human life (Wilkins and Reynolds 2006 Ave Maria $L J$ 164). Also see Sloane 2001 Vanderbilt J Transnat'I L 544.

3 Jenks 1954 BYIL 5. Also see Paul 1995 Harv Int'I L J 319 fn 68 . The preamble to the United Nations Charter (1945) para 1: "Whereas recognition of the inherent dignity and of the equal and inalienable rights of all members of the human family is the foundation of freedom, justice and peace in the world ..." If it is the case that international human rights norms are inclusive of respect for the dignity of all human beings (or of anything on the immediate periphery of "being human"), any failure to address dignity in relation to the unborn can be viewed as a failure to apply these norms consistently.

4 Sloane 2001 Vanderbilt J Transnat'l L 553. Kory Sorrell comments that the idea that human rights are universal and provide the best available framework for constructing common norms among nations and across cultures is rhetorically powerful and attractive: "It is deeply inclusive, providing a 'picture' in which all persons, however culturally and historically diverse, may recognize themselves and see others as having something important in common with them, their 'humanity'" (Sorrell 2003 Tulsa J Comp \& Int'l L 370).

5 Jenks 1954 BYIL 35. 
Although substantial development has taken place in international human rights law, the international community ${ }^{6}$ has not formally approached the legal status of the unborn as a matter of urgency, thereby possibly suggesting that there is a general disregard of the rights of the unborn. The "complexity" of the relevant issues and the fact that there are "disparate" views of the matter should not be thought to justify the failure to address the matter. ${ }^{7}$ Close analysis of the legal status and protection of the unborn in international law in general and many domestic legal systems suggests that the determination of when the entity becomes human is not left entirely to the mother (although this is the dominant approach), and that the matter is generally considered to be important. This sense of the importance of the matter should motivate the legal establishment to attempt to develop a deliberative platform on the legal status and protection of the unborn. This would be an informed and impartial framework based on the inclusion of all points of view and constructive communication among those who disagree with one another. The challenge, though, is to convince the establishment that it is important that we have such a conversation in the first place.

Consequently, this article argues for the establishment of a deliberative platform pertaining to the legal status and protection of the unborn in international law. It should be possible for such deliberations to be conducted with sensitivity towards the status of the unborn (irrespective of the stage of pregnancy). ${ }^{8}$ The first part of this

6 That is, the United Nations (General Assembly) and the member states to international and regional human rights conventions.

7 For anyone familiar with abortion jurisprudence this will surely ring a bell, as some ethical theorists and court decisions have referred to the "complexity" of determining the status of the unborn as reason (whether directly or indirectly) for not having to further delve into the issue.

8 It is not the purpose of this article to make an argument regarding the period within pregnancy when the unborn should receive protection. The fact remains that presently no formal commitments towards arriving at this determination have been made by the international community. Generally speaking, the abortion legislation of states does tend to provide protection to the unborn from approximately the third trimester (this is when viability is established) of pregnancy (with certain exceptions such as rape, incest, serious deformity and the pregnancy's constituting a threat to the mother's life). This should be common knowledge in abortion jurisprudence. However, this determination has not been addressed or confirmed from an international law perspective. There are other important issues related to the unborn to which the establishment of the said deliberative platform will also contribute, such as the following: (1) that states commit themselves to the proper observance of abortion legislation (including the establishment of proper sanctions where such legislation is violated); (2) that the psychological and physical interests of the mother are duly protected in legislation regarding the proper transference of information pertaining to the status of the unborn so that a truly informed decision 
article therefore investigates the extent to which international instruments provide protection to the unborn and arrives at the conclusion that the position of the unborn in international law is, generally speaking, rather vague. This perception, together with the perception that substantial developments have taken place in international law pertaining to cloning as well as to the rights of women, children and even animals has provided the impetus for the proposal for the establishment of a deliberative platform regarding the protection of the unborn. Consequently, the second part of this article argues for the establishment of such a deliberative framework so as to further the recognition of the unborn in international law. In this regard, it is argued that debate on the legal status and protection of the unborn can be effective against the background of a procedurally-rational approach aimed at inclusivity as well as at constructive participation and communication. However, although this article emphasises the legal status of the unborn and the need to establish a discursive platform, it does not express a definite view about the point in time of a pregnancy or the stage of development of the foetus when the unborn should receive protection in international law.

\section{International law and the unborn}

The contemporary jurisprudential milieu (nationally and internationally) is reflective of a bifurcated narrative on the unborn. On the one hand, the narrative is epitomised by the restructuring of criminal codes in order to protect the unborn from violent actions, ${ }^{9}$ bioethical efforts related to the human embryo, ${ }^{10}$ and substantive anti-

can be made by the mother; (3) that states commit themselves to rooting out "backstreet" abortion practices; (4) that abortion should not be viewed as a means of contraception and that effective and relevant educative structures accommodate and proclaim this understanding; (5) that structures should be supported for the establishment or furtherance of civil society (and governmental) initiatives which can assist in the provision of the necessary socio-economic services in instances where the mother decides not to proceed with the abortion; (6) that states promote the relevant education on the implications of teenage pregnancy; (7) that states attend to enacting legislation on the criminalisation of the intentional killing of the unborn in instances where the mother intended to continue with the pregnancy; (8) that efforts should be put in place limiting sex-selective abortion as well as female infanticide; and (9) that steps be taken towards the accommodation of those who do not want to be involved in abortion practices in any manner whatsoever.

9 An example of an event where criminal codes in the United States are being restructured to protect the unborn from violent actions is 'foeticide'. 'Foeticide' refers to an instance where the death of the unborn is caused by a person other than the mother (and without her consent). Thirty-five of the states in the US have statutes criminalising the killing of an unborn child outside the domain of legal abortions (Magnuson and Lederman 2007 Wm Mitchell L Rev 767, 770). However, while only some of these states provide complete protection for the unborn, all of them 
abortion sentiment within many communities. On the other hand there is the view supporting the subordination (not necessarily in an absolute sense) of the unborn to maternal liberty. The former narrative tends to define the unborn as "human beings", "persons" (or "something" very similar to a person or a human being), while the latter narrative manifests itself most pronouncedly in the constitutional right to abortion. ${ }^{11}$ The contemporary approach to the legal status of the unborn, as witnessed in the statutes of many states, does not leave the determination of "foetal value" or "having no foetal value" solely to the mother. ${ }^{12}$ Also, many international and regional law instruments are vague on the legal status of the unborn, ${ }^{13}$ whilst some instruments clearly support the protection of the unborn. ${ }^{14}$

provide at least some protection (Magnuson and Lederman 2007 Wm Mitchell L Rev 770-771). Also see: Klasing 1995 Pepp L Rev 933-979; Parness 1985 Harv J Leg 97-172; and Tsao 1998 Hastings Const $L Q$ 457-481. It is interesting (and also perplexing) that, irrespective of this development in criminal law, the US pioneered the "pro-choice" (pro-abortion) stance as reflected in the decision of Roe $v$ Wade 410 US 113 (1973).

Fenzel 2007 Focus 34-37.

Milligan 2007 Baylor U L Rev 1178.

12 The abortion laws of approximately $64 \%$ of 119 states allow for abortions based only on: (1) a risk to life and health (physical and/or mental); (2) rape; and (3) foetal defect (hereby excluding "demand" and "social factors" as possible legal qualifications for an abortion). Included in the said percentage are no less than 46 African states, making the issue, from an African perspective, rather important (Pregnantpause (year unknown) www.pregnantpause.org).

13 According to Jude lbegbu, although the provisions in human rights treaties are stated in such a way as to grant a right to "everyone" or to all "human beings", none of these terms have been closely defined by international organs, with specific reference to the United Nations (Ibegbu Rights of the Unborn Child 105). Also see Ibegbu Rights of the Unborn Child xxvii, xxviii and 2-3. Philip Alston states that although the Preamble to the Convention of the Rights of the Child (CRC) could suggest that a wide range of measures exists by means of which the interests of the unborn child can be promoted and protected without going so far as to recognise a right to life from the moment of fertilisation, the vagueness of the preambular provision and its failure to address any of the complex issues which a right to life of the unborn would raise serve to reinforce the assumption that it could not have been intended to have any precise operational implications (Alston 1990 Hum Rts Q 174). In this regard, also see Slabbert 1999 CILSA 339; Mower Convention on the Rights of the Child 28-30; and Sloth-Nielsen 1995 SAJHR 411-412. Rita Joseph states: "... though the 1959 DRC [Declaration of the Rights of the Child] may not be legally binding in itself, nevertheless its legal force lies in the formal and irrefutable evidence it provides that as at 20 November 1959 the whole international community understood and agreed that the UDHR (legally binding today as customary law) had for that first decade of its jurisdiction already recognised the legal status of the child before birth and his entitlement to human rights protection. Universal recognition of the child before birth as a juridical personality entitled to legal protection had been established and accepted in the very foundation instrument of modern international human rights law." (Joseph Human Rights and the Unborn Child 3). (Also see Joseph Human Rights and the Unborn Child 45, 81-82, 103, 108, 135, 193, and 195). Uncertainty also exists as to if the right to life is granted to the unborn by the African Charter on Human and Peoples' Rights (1986) (Petersen 2005 ZAÖRV 457).

14 Amidst vagueness on the legal status of the unborn in international law instruments, there are indications of some sensitivity towards the unborn, for example a 6(5) of the International Covenant on Civil and Political Rights (ICCPR) states that the death penalty is not to be carried out on a pregnant woman. $\mathrm{n}$ this regard see Slabbert 1999 CILSA 339. Also see, lbegbu Rights of the Unborn Child 117 and 119-120; Petersen 2005 ZAÖRV 450; and Flood 2007 NCBQ 76. The African Charter on Human and Peoples' Rights (1986) in a 4(1), makes explicit reference to 
In contrast to the abortion debate, the debate on cloning has been inclusive and sensitive to several areas affecting the issue. ${ }^{15}$ Robert Araujo states that one of the most important recent declarations issued by the United Nations was its call to end all human cloning. ${ }^{16}$ In March 2005, the General Assembly accepted the recommendation despite its inability to achieve consensus and passed the United Nations Declaration on Human Cloning by a vote of eighty-four in favour, thirty-four against, and thirty-seven abstentions. ${ }^{17}$ Although inconsistencies exist, the United Nations' baby steps toward an international convention to ban human reproductive cloning are important primarily because they mark the first attempt to develop an international framework for responsible social governance of a human genetic technology. ${ }^{18}$ An international treaty banning human cloning may not be the perfect solution; it will probably lack universal acceptance, and it will take years to establish. However, says Elizabeth Shanin, the development of such a treaty will initiate an international discussion regarding the consequences of human cloning, and the enforcement of such a treaty will inevitably lead to some international regulation of cloning technology. ${ }^{19}$ In contrast to the abortion matter (and a quest towards furthering some or other deliberation on the unborn) the approach has been one

a pre-natal right to life. The Protocol to the African Charter on Human and Peoples' Rights on the Rights of Women in Africa (2003) in a 14 of the said Protocol, explicitly provides for "Health and Reproductive Rights", and infers the protection of the unborn in that legal protection for the unborn is denied in the case of rape, incest, sexual assault and where the pregnancy endangers the mental and physical health of the mother or the life of the mother (a 14(2)(c)).

15 The expert panel that attended the first meeting in 2002 regarding the gestating of a United Nations Cloning Convention was criticised for not representing all regions of the world, and for not conveying a clear message about the risks and societal implications of human reproductive cloning (Isasi and Annas 2003 Case W Res J Int'l L 406). To distinguish such an initiative from an initiative endeavouring to deliberate on the legal status and protection of the unborn surely does not make sense. Also, for the contemporary efforts dealing with the embryo and bioethics, see Fenzel 2007 Focus 34-37.

Araujo 2007 NCBQ 129

Jarrell 2006 Ga J Int'l \& Comp L 225-226. The Declaration "prohibits all forms of human cloning inasmuch as they are incompatible with human dignity and the protection of human life". Since the Declaration is non-binding, it seeks "to protect human life in the application of life and reproductive sciences, by urging member states to adopt domestic legislation compatible with the Declaration's text". The General Assembly adopted this Declaration while "aware of the ethical concerns that certain applications of rapidly developing life sciences may raise with regard to human dignity, human rights and the fundamental freedoms of individuals". Although nations were split on whether or not to have a complete ban on all forms of cloning, the United Nations attempted to alleviate the confusion with the adoption of the United Nations Declaration on Human Cloning (Jarrell "No worldwide consensus: The United Nations Declaration on Human Cloning" 2006 Ga J Int'l \& Comp L 225-226. Also see the United Nations Declaration on Human Cloning (2005).

18 Isasi and Annas 2003 Case W Res J Int'I L 399.

19 Shanin 2002 Chicago J Int'l Law 255. 
where, although a treaty may not be perfect, and is lacking in universal acceptance, it did initiate some international discussion and consequent regulation of cloning technology.

Although international law has shown development in human rights jurisprudence and has taken giant steps towards the protection of women's ${ }^{20}$ and children's rights ${ }^{21}$ and even animal welfare, ${ }^{22}$ its deliberate avoidance of establishing and developing a conducive, inclusive, and tolerable approach towards furthering the discussion on the legal status of the unborn needs to be noted and reversed. ${ }^{23}$ In fact, the conduciveness of a paradigm such as international law to such debate also requires emphasis. $^{24}$

20 Reproductive choice rights are seen as one of the most important rights where measures are needed to reach substantive equality between men and women. It has been held that men are not similarly affected by pregnancy and therefore the burden of an unwanted pregnancy is discriminatory (Eriksson Reproductive Freedom 276-277). Women are unable to shape their lives and are "subjugated by their reproductive role which is determined by society at large and by their husbands in particular" (Packer Right to Reproductive Choice 8). Therefore, the view is that a woman's equality and status is reduced because she cannot control an unwanted pregnancy. According to Corinne Packer, the general feminist view is that women's self-determination should bring them to a level of equality in their reproductive choice rights. It is understandable, says Packer, that reproductive choice should be addressed in a UN Convention on the Elimination of all forms of Discrimination against Women (1979). Clearly, freedom in fertility decision-making plays a central role in making overall equality achievable (Packer Right to Reproductive Choice 8-9.)

21 The 1989 Convention on the Rights of the Child indicated international acceptance of the human rights of children. The Convention now establishes legally binding norms and principles which create international standards for states to meet in their domestic legislation and policy concerning areas covered by the Convention (Sloth-Nielsen 1995 SAJHR 402).

22 An International Convention for the Protection of Animals has been proposed (proposed text from Animal Legal and Historical Center). See Georgetown Law Library (year unknown) www.ll.georgetown.edu. Also see Our Dogs Shop (year unknown) www.ourdogs.co.uk; Michigan State University College of Law: Animal Legal and Historical Centre (year unknown) www.animallaw.info; Uncaged (year unknown) www.uncaged.co.uk; and European Union (date unknown) eur-lex.europa.eu.

In fact, there are recent efforts to investigate the difficult relationship between ethics, morality and law in view of the advances made in biotechnology and biomedicine at the national and international level. See Fenzel 2007 Focus 34-37.

International law does not, generally speaking, represent such a "closed" jurisprudential system as in domestic legal systems pertaining to the matter at hand. This is explained in the following: regarding the legal status and protection of the unborn, international law has not to date substantively and formally approached the legal status of the unborn (as against many domestic legal systems), while the moral issues related to cloning, genetic engineering and animal rights, for example, are receiving attention. International law also lends itself towards a strong natural or moral law ideological foundation and this makes it an ideal platform for discussion on the unborn and the starting point of being human. International instruments, albeit vague in many instances, have the potential to accommodate various views on the status of the unborn, as well as the fact that the practice by states generally reflects sensitivity towards the unborn (whatever the phase of pregnancy). Then there is also the moral obligation of international law pertaining to checks and balances regarding the proper execution of pro-abortion legislation around the world. One would not want a repetition of the negation regarding the legal status and protection of the 


\title{
3 Towards a deliberative platform
}

\author{
According to Christian Tomuschat, ${ }^{25}$ discourse on issues of international law must be \\ accompanied by meaningful dialogue foregrounding the common basis of \\ understanding of controversial issues:
}

Discourse on what is right or wrong must be crystal-clear and should not fall into the hands of a few magicians who invariably are able to prove that law and justice are on their side. ${ }^{26}$

This should be the case in international deliberation on the legal status and protection of the unborn, in accordance with Daniel Callahan's ${ }^{27}$ proposal that a minimal moral consensus is required in a pluralistic society on the doctrine of the sanctity of life: ${ }^{28}$

I believe it is possible to discern considerable agreement among the different western moral sub-communities, at least if one remains at a fairly high level of abstraction and generality. 29

unborn on an international level, as found in the proposed discussion related to the Statutes of the International Criminal Court (ICC). In this regard, the Caucus for Gender Justice (headquartered at the law school at the City University of New York) was instrumental in framing the debate on "forced" or "enforced" pregnancy, and various versions of the draft ICC statute listed the concept as a "war crime", or as a "crime against humanity". "Forced" or "enforced" pregnancy was designed to create a world-wide right to abortion on demand, and western nations, as well as hundreds of NGOs, pushed for the inclusion of this new "crime" in the ICC statute: "they adamantly resisted any effort either to define or limit this previously unknown offence" (Wilkins and Reynolds 2006 Ave Maria $L J$ 136-139). The composition of this discussion group reflects the arbitrary, misrepresented nature of such discussion, which is neither fair nor rational. In this regard, there were exceptionally few anti-abortion law professors and law students engaged full-time at the conference in Rome; perhaps only three. In addition, during the actual course of negotiations, the tactics of the abortion proponents were highly questionable, involving at various times parliamentary evasion and procedural irregularities, as well as outright disavowal of previously stated and published positions (Wilkins and Reynolds 2006 Ave Maria L $J 142-143)$.

Tomuschat 1999 Recueil Des Cours 26.

Von Bogdandy 2006 Harv Int'l L J 227.

Callahan "Sanctity of Life Principle" 84.

28 Although Callahan is moving towards a certain solution of a minimum jurisprudence, one must bear in mind that the concept of "life" as a point of departure is in itself opinionated. However, for the purposes of this article, this is an irrelevant observation.

29 Callahan "Sanctity of Life Principle" 93. Although it may be argued that contemporary formulations of the various and relevant international instruments already provide some level of abstraction and generality pertaining to the unborn, there needs to be (as argued in this article) a more concerted effort towards attaining a more accurate and formal view on the legal status and protection of the unborn in international law, specifically. 
This view, that there is a minimal moral consensus, reminds one of Joshua Cohen's view of the importance of an 'overlapping consensus' which he terms 'justificatory minimalism', ${ }^{30}$ which is informed by an acknowledgement of pluralism and an insistence on tolerance. Such an attitude aspires to present a conception of human rights without itself connecting that conception to a particular ethical or religious outlook. $^{31}$ It presents us with a "...practice of argument that aims to clarify and perhaps narrow the terms of disagreement". ${ }^{32}$ Stephen Macedo proposes that those engaged in such deliberations should exercise "moderation", which goes beyond tolerance, in their effort to reach agreement on "hard" cases. ${ }^{33}$ Macedo states that the abortion question, for example, is so enigmatic because there are weighty considerations on both sides of the argument. The best thing, according to Macedo, for reasonable people to do might be to acknowledge the difficulty of the argument and the burdens of reason, to respect their opponents and to compromise with them, to find some middle ground that gives something to each side while the argument continues. The right kind of middle ground on abortion would acknowledge both the judgment of the mother and the fact that this choice concerns the continuance of another life. Macedo ${ }^{34}$ states:

[Such a compromise] would, perhaps, honour a woman's choice up to a certain point in the pregnancy and also countenance a variety of measures that would not be permitted were abortion simply a matter of an individual's right to choose: measures to ensure at least that the choice is reflective and informed.

$30 \quad$ Cohen "Minimalism About Human Rights" 422.

31 Cohen "Minimalism About Human Rights" 421. In fact, in no instance should rights be viewed as merely protections against the state, but also as a mode of discourse for advancing and justifying claims (Ghai 2000 Cardozo L Rev 1137).

32 Cohen "Minimalism About Human Rights" 424.

33 Macedo 1990 Political Theory 296.

34 Macedo 1990 Political Theory 296-297. Annette Clark observes: "Legal academics choosing to enter the abortion fray have tended to respond in two ways. The first and by far the most common response has been to defend from a legal and jurisprudential standpoint either the prochoice or pro-life position. The other, less common response has been to search for a compromise on the abortion question... Compromise implies mutual agreement through mutual concessions... It is even more inviting in the abortion context because those who advocate compromise hold out the promise of an end to the divisiveness engendered by the current abortion debate ..." (Clark 1993 NY U L Rev 273). To the enquiry as to why the search for compromise on the abortion question is the "less common response", Clark responds: "... those who wish to advance pro-life or the pro-choice position politically have little incentive to explore other possibilities or to validate the beliefs of anyone who chooses not to join their crusades. The very deliberate choice of war rhetoric perfectly embodies the message that this is a war with battles to be fought, skirmishes to be won or lost, an enemy to be defeated... When winning is the goal of two opponents, advocates of a third view are at best a distraction and at worst a threat. Thus, left to their own devices, the two most vocal combatants will narrow the choice of options to two" (Clark 1993 NY U L Rev 297-298). Also see Clark 1993 NY U L Rev 300-301. 
Cognisance needs to be taken of the fact that opposition to abortion does not, of itself, constitute an attack on a woman's right to respect for privacy in her life. ${ }^{35}$

Bearing the above in mind, the complexity inherent in initiatives aimed at the establishment of a deliberative platform also requires consideration. Robert Lipkin refers to the contemporary post-modernistic challenges levelled against the Enlightenment's (failed) rationalist-project, eventually resulting in scepticism, relativism, and nihilism. ${ }^{36}$ Resulting from this is the view of "conversationalism", that intellectual history is replete with failed attempts at achieving agreement. According to those who hold this position, the fact that the very best of the hearts and minds of civilisation have failed to achieve agreement over controversial issues is powerful evidence that resolution is unlikely. ${ }^{37}$ Michael Freeman ${ }^{38}$ agrees with a rational approach but also notes that history shows that reasonable persons can disagree on such rules. Reasonable persons disagree over religious doctrines, the ultimate conceptions of the good life, the levels of the public provision of education and health care, social security, defence policy, environmental preservation and several other issues that liberal societies determine by legislative action. ${ }^{39}$ Every person believes that his or her personal insights are universally valid. ${ }^{40}$ lan Charles Jarvie ${ }^{41}$ explains this as the problem of sustaining the principle of their being a rational unity in mankind in the face of a vast diversity of achievements and especially of culture, society and cognition (even of ideology). It may be that competing actions, beliefs and desires may all qualify as rational, and that there is no universal agreement as to what is rational. ${ }^{42}$ What certainty there is in law regarding the stage at which the unborn attains legal status changes with the point of view of the person who holds such a certainty, and ranges from conception, through the end of the first trimester of pregnancy, to the point of viability, the moment of birth and sometimes even after

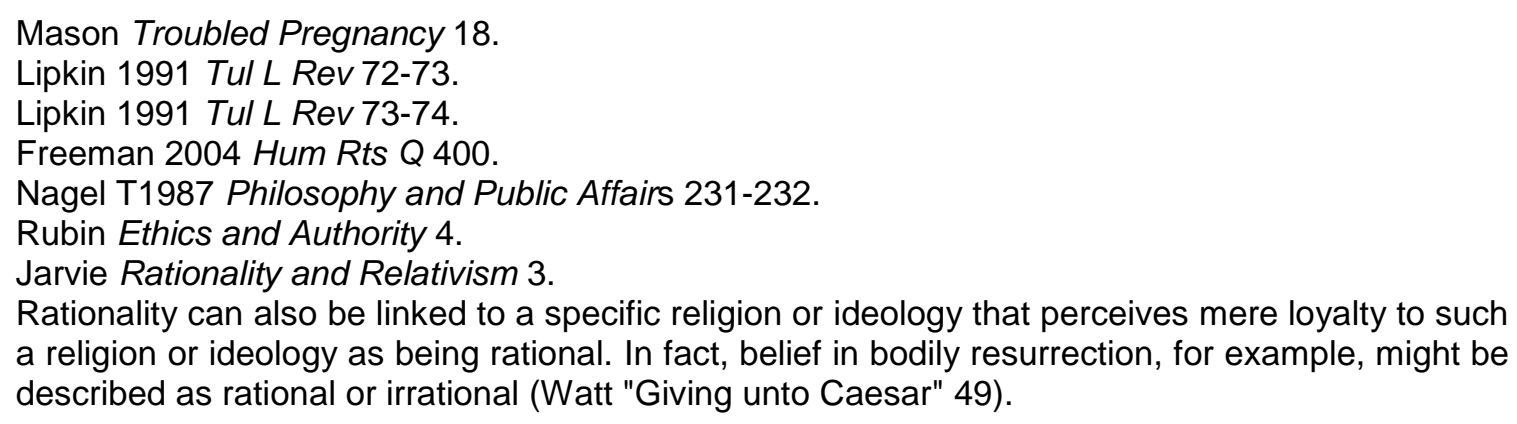

Rationality can also be linked to a specific religion or ideology that perceives mere loyalty to such a religion or ideology as being rational. In fact, belief in bodily resurrection, for example, might be described as rational or irrational (Watt "Giving unto Caesar" 49). 
birth. ${ }^{43}$

Should we then continue to search for common ground and development regarding the legal status of the unborn? Matthew Ritter disagrees that differences of opinion are a disadvantage to rational discourse. Pluralism plays a necessary part in forming a community of discourse with mutual understanding, tolerance, and respect required for the development of a political community. According to Ritter, it is only by virtue of talking to one another that we know our real differences, and may therefore truly communicate with one another and mediate consensus and dissensus. ${ }^{44}$ What matters is the opportunity for discourse - the process and its rules. $^{45}$ It is through interaction that different groups, countries and religious communities, while holding incompatible fundamental views on theology, metaphysics, human nature and so on, would come to an agreement on certain norms that ought to govern human behaviour. ${ }^{46}$ What is sought, according to Thomas Nagel, is a solution that is open-ended in the possibility of its investigation and pursuit, and that does not descend finally into a bare confrontation between incompatible personal points of view. ${ }^{47}$

Nagel states that public justification in a context of actual disagreement requires, firstly, preparedness to submit one's reasons to the criticism of others and to find that

43 Handler and Jack Ballentine's Law Dictionary 308. Also see Warren Moral Status 26.

44 Ritter 1997 Cal W Int'I L J 284-285.

45 Franck Fairness in International Law 3.

46 Taylor "World Consensus" 411. This idea was expressed in 1949 by Jacques Maritain: "I am quite certain that my way of justifying belief in the rights of man and the ideal of liberty, equality, fraternity is the only way with a firm foundation in truth. This does not prevent me from being in agreement on these practical convictions with people who are certain that their way of justifying them, entirely different from mine or opposed to mine ... is equally the only way founded upon truth" (Taylor "World Consensus" 411). We find similar contemporary efforts pertaining to the legal status of the embryo in the context of bioethics. It is stated that: "Ethical decisions in the biotechnology sphere are at least as complicated as they are in the field of environmental protection. 'What makes them especially difficult is that pluralistic societies are rarely able to reach common ground with regard to their political and legal views', says Vöneky, describing the crux of the problem relating to morality and the law" (Fenzel 2007 Focus 34). Nevertheless there is (international) debate on the legal status of the embryo in bioethics, for example (but not for abortion).

Nagel 1987 Philosophy and Public Affairs 232. In the context of contemporary efforts to gain clarity and consensus on bioethical issues related to the status of the embryo, Vöneky, quoted in Nagel, comments that where substantive standards cannot be formulated, the procedure for determining standards needs to be designed in a way that fosters agreement - "this shifts the focus from the content of the decision to the decision-making mechanisms themselves. The aim is to ensure quality, not through the content, but through the procedure" (Fenzel 2007 Focus 37). The same dictum should be applied to efforts towards establishing international participation pertaining to jurisprudence dealing with the status of the unborn. 
the exercise of a common critical rationality and consideration of evidence that can be shared may reveal that one is mistaken. ${ }^{48}$ Secondly, public justification requires an expectation that if others who do not share your belief are wrong, there is probably an explanation of their error which is not circular. The explanation should not come down to the mere assertion that they do not believe the truth (what you believe), but should explain their false belief in terms of errors in their evidence, or identifiable errors in drawing conclusions from it, or in argument, judgment, and so forth. ${ }^{49}$ Frank Michelman proposes an argumentative interchange among persons who recognise one another as equal in authority and entitlement to respect. In this regard, the participants direct their arguments toward arriving at a reasonable answer to some question of public ordering, meaning an answer that all can accept as a good-faith resolution when circumstances demand some social choice. ${ }^{50}$ Michelman adds that a deliberative style of politics may be confrontational, contestative, and fully compatible with pluralistic political sociology. Although notions of deliberative politics may be framed as presupposing the existence of objectively discoverable, transcendently right answers, deliberative politics need not carry such dogmatic baggage..$^{51}$

The attitude of openness to persuasion and the perspectives of others aimed at conciliation with reason also provides a constructive way of attaining a properly thought-through process in which a vast overarching theoretical system of complex principles about the nature of a specific category of the law is the context. ${ }^{52}$ The relevance and application of the law is determined by contexts and ideologies, and consequently this affects the degree of qualification regarding the relevance and application of rationality (and universality). However, attempting the application of

Nagel 1987 Philosophy and Public Affairs 232.

Nagel 1987 Philosophy and Public Affairs 232.

Michelman 1989 Fla L Rev 447.

51 Michelman 1989 Fla L Rev 447-448. In the words of Michelman: "Deliberation does presuppose a certain kind of civic friendship, an attitude of openness to persuasion by reasons referring to the claims and perspectives of others. The deliberative attitude aims not at dissolution of difference but at conciliation within reason. The deliberative medium is a good-faith exchange of views - including participants' reports of their own understandings of their respective vital interests - in which all remain open to the possibility of persuasion by others" (Michelman 1989 Fla L Rev 447-448).

52 Dworkin 1997 Ariz St $L J 354$. "To be open-minded is to be sensitive to the possibility that one may not yet have succeeded in being as impartial and as objective as one may have intended and hoped; that there may still be new facts to be discovered, old facts whose relevance has yet to be reassessed, new interpretations to be considered of the total situation or of certain aspects of it" (Montefiore "Neutrality, Indifference and Detachment" 21). 
rationality (and universality) towards a convincing level (a level that may seem more likely than another), is in fact possible and useful in many situations. This would be the wiser and procedurally-rational option when compared with the high level of apathy towards the legal status of the unborn. Rationality becomes possible in the context of impartiality because impartiality does not require futile efforts to be neutral, but in the context of the legal status of the unborn, will require participants to argue in a non-arbitrary manner, with a "mind, open to persuasion by the evidence and the submissions of counsel". ${ }^{53}$ Therefore, impartiality will require participants to the debate on the legal status of the unborn to be sensitive to other ideologies and evidence presented on the unborn, and not merely to assume that their views are the deciding factor.

An approach based on a desire to be impartial and to participate in an informed manner would lead to greater intelligibility in the discourse. According to Nicholas Rescher, anything that expands our informational horizons clearly enhances the epistemic basis of our beliefs. But what validates these communal processes in inquiry is not a preconception that reaching consensus is the governing goal; it is only the consideration that in the epistemic and evidential domain bigger is better that more amply evidentiated conclusions are for that very reason better substantiated, and that taking the beliefs of others into account is one way to broaden our evidential basis. ${ }^{54}$ Rescher adds that the primary objects of communication are (1) to extend one's information and (2) to solidify one's information (by testing it against the facts and opinions available to others and seeing if any reasons to change one's mind come into view). In this regard, even disagreement is informatively useful - after all, it suggests that we may not "have it right" after all. Reaching an agreement - the aligning of one's views with those of one's interlocutor - is almost certainly not a substantial part of the communicative agent's objective. The alignment of views - the reaching of a consensus on the issues - is neither a precondition nor a goal of the cognitive enterprise. ${ }^{55}$

53 See the Constitutional Court judgment of SA Commercial Catering and Allied Workers Union v Irvin and Johnson Ltd (Seafood Division Fish Processing) 20008 BCLR 886 (CC) 893.

54 Rescher Pluralism 59-60.

55 Rescher Pluralism 152-153. Rescher also states that, in communication, it is not agreement but intelligibility that is the name of the game; what we both hope for and expect is not endorsement but information. What experienced and realistic communicators expect to achieve in communicative exchange is "a mutual clarification of positions" - an understanding of where the 
The route of rational discussion is replete with obstacles. However, when dealing with "hard" issues such as abortion, the international community should be obliged by the humane tones of the United Nations Charter, 1945 and by the dictates of procedural rationality to pursue a route that acknowledges the dignity of all participants. Issues related to cloning and genetic engineering "are similarly complicated", yet are receiving more attention. The mere fact that conversation is possible, whether at an inter-individual or inter-societal level, confirms that there is a universal rational basis making communication possible in the first instance. If this were not the case then the world would be in a chaotic state due to the impossibility of communication and agreement. International human rights instruments also indicate that there is a universal affiliation towards certain foundational norms which inherently seem moral. Therefore, discussion (deliberation) on the plight of the unborn in international law should be more than a mere pipe-dream. The elements of a procedural rationality that could further the legal status and protection of the unborn are tolerance, accommodation, orderly conversation, mutual respect, openness to persuasion, accessibility of communicative structures, and impartiality. However, the meanings and parameters of these elements would require further critical analysis, discussion and deliberation (nor should this list of elements be exhaustive). This article does not claim to present ultimate answers, but it claims that the lack of any previous attempt by the international legal community over a considerable period of time to establish a deliberative platform regarding the legal status and protection of the unborn necessitates the development of ideas about what is required to get us to a point of departure in this matter. ${ }^{56}$

other party stands and why this involves commitments that differ from ours (Rescher Pluralism 154).

56 Many will claim that there are incommensurable positions involved in the debate about the legal status of the unborn. Such an assertion rules out (in a dogmatic and inappropriate fashion) the very possibility of deliberation and the possibility of reaching an agreement. It is important also to note that theories neither generate actual agreements out of diverse positions nor do they derail the process of achieving agreement. What critical theory can do, however, is to show how agreements that are rationally grounded but respectful of difference (and therefore nonoppressive), might be possible in the pluralist context of international law and a modern complex society. This idea is taken from O'Neill 2000 Political Studies 505. What is aimed at in this article is similar to O'Neill's postulation that what is sought is "a structural account of the cultural values that foster human relations in which citizens would be willing to engage in a deliberative form of democratic politics by committing themselves to work their way beyond an incommensurability of positions towards a reasoned agreement. Values such as tolerance, fair-mindedness, openness and sensitivity to difference will all feature in such a structural account" (O'Neill 2000 Political Studies 518). 


\section{Conclusion}

In connection with Tomuschat's view that current international law contains many features that allow for its evolution into a "common law of humankind", Von Bogdandy believes that this may well be the case with respect to the effort to achieve the recognition of the unborn in international law. ${ }^{57}$ Those who call for such recognition certainly cannot ignore the potential consequences of determining some or other minimum standard in this regard. This does not necessarily imply the formulation of any "hard law" (for example a convention) pertaining to the legal status of the unborn, nor is the exclusive participation by states the route to follow. The mere establishment of a communicative structure including representatives of states, international organisations and organisations of international "civil society" 58 (for example religious and cultural groups) would do much to further the status of the unborn in international law. There is ample evidence to confirm that the "language" of the discourse at UN-sponsored negotiations now shapes and solidifies international and national law. This is especially true for international norms dealing with such issues as human reproduction, for example. ${ }^{59}$ Where precisely the interests of both the mother and the unborn need to be limited still needs to be determined, as stated earlier. Nevertheless, there should be certain minimum requirements. The protection of human life, well-being and dignity are essential aims of the United Nations Charter, 1945 and the international system created to implement it. The said Charter imposes a compelling legal obligation on all member states and on UN institutions and intergovernmental agencies to work together to promote "human rights", among other things, through collective efforts. ${ }^{60}$ The international community should be continuously reminded of the law's service to

\footnotetext{
57 Von Bogdandy 2006 Harv Int'I L J 237; Tomuschat 1999 Recueil Des Cours 88.

58 For the importance of civil society in international law, see Falk and Strauss "Deeper Challenges" $1442-1444$.

59 Wilkins and Reynolds 2006 Ave Maria $L J$ 123. Here the authors add that "by means of prose at turns lofty and unintelligible, and somewhat incongruously disclaiming lawmaking intent, international policymakers are redefining the legal, social, moral, and ethical value of human life" (Wilkins and Reynolds 2006 Ave Maria L J 124). Wilkins and Reynolds refer to James Paul's comment that: "Because world conferences provide potential opportunities for global popular participation, expert consultations, and, sometimes, vigorous debate, they can, in theory, become unique vehicles to elaborate norms (cast in the form of legal instruments) governing development" (Wilkins and Reynolds 2006 Ave Maria L J 130). 
humanity, and not lose sight of the inherent and continuous commitment towards developing a clear understanding of the legal status of each and every unborn individual being.

The gross violations of common mores at a domestic level, violations that occur in the context of permissive legislation, also require attention. Backstreet abortions towards the last trimester of pregnancy take place in many countries, for example. In many instances, abortion clinics do not adhere to the relevant pro-abortion laws, and the authorities turn a blind eye in this regard. All of these infractions are indicative of a disrespectful attitude towards mankind and need to be addressed by the international community. ${ }^{61}$ States also need to consider the effect an abortion has on a woman. A woman is required in law to give informed consent, ${ }^{62}$ and needs to make decisions with the highest quality of information provided to her. Terry Steinberg's article investigates the effects of abortions on women and the failure of the law to address these effects. ${ }^{63}$ There is evidence of the fact that abortion clinics too often fail to provide adequate information to women seeking abortions. ${ }^{64}$ As a result, many women are physically and psychologically harmed by the abortion process. ${ }^{65}$ Then there is the problem of sex-selective abortion and female infanticide (forced abortion). Robert Araujo observes that many who advocate the protection of and redress of abuse against young women and girls have had a particular concern regarding the aborting of the unborn female. ${ }^{66}$ International participation in the

61 Jürgen Habermas, in his book, The Future of Human Nature, argues that respect for what he calls pre-personal human life is essential to our ethical self-understanding of humanity as a whole; that is, of what it means to be human. See also Somerville "Birth, Death, and Technoscience" 107.

Informed consent is a legal phrase meaning that a person must be fully informed of a medical procedure before giving true consent to that procedure. In the abortion context, it means that the woman is fully informed of the risks, alternatives, and other important medical information concerning the abortion. If a woman is not fully informed of what the procedure and its consequences will be or could entail, her consent is not legally valid (Smith 2008 www.aul.org). Steinberg 1989 AJLM 484. According to Steinberg, an abortion, as an event in a woman's life, encompasses more than just the procedure itself. It means choosing one path over another. Any abortion counseling must assist the decision-making prior to and alleviate distress after abortion (Steinberg 1989 AJLM 485). Also see Siegel 2008 Yale L J 1697-1698, 1700-1701. Also see Smith 2008 www.aul.org; Collett 2008 SC L Rev 731-732.

64 Abortion is the only invasive medical procedure where the generally accepted requirements of informed consent are controversial and disregarded (Smith 2008 www.aul.org).

65 Smith 2008 www.aul.org.

66 Araujo (year unknown) www.fww.org. Araujo adds that "if the unborn female child is to be protected, then so is the male child to be protected" (Araujo (year unknown) www.fww.org). Rumage points to the fact that sex-selective abortion is viewed by modern scientists as having significant consequences. Demographers warn that the "high preference for sons in China 
deliberations regarding the legal status of the unborn would therefore be relevant not only to the unborn but also to the mother herself.

Not to attempt to establish a deliberative platform addressing the legal status and protection of the unborn would be to deny man's inherent desire to understand himself or herself more clearly, and to frame laws that would lead to the further preservation of humanity and human dignity. Consideration needs to be given to Jude Ibegbu's proposal for the establishment of a special Committee on the Human Rights of the Unborn Child in International Law, to monitor the fulfillment by states parties of obligations regarding the legal status of the unborn. Ibegbu also proposes the appointment of a special Commissioner for the promotion and protection of the human rights of the unborn child in international law and the establishment of a compulsory course on the human rights of the unborn child in all institutions at all levels of education. ${ }^{67}$ This will require concerted efforts towards a deliberative and accommodative approach based on procedural rationality and fairness and inclusivity.

There are no guarantees that the deliberations proposed here will take place, nor does this article aim at providing definite answers regarding at what point of time during pregnancy or at what stage of development of the foetus the unborn requires protection in international law. However, it behooves man, on an international scale, to join in on the journey not only towards self-preservation, but also towards added sensitivity regarding that which cannot be seen as separate (whether entirely or partly) from mankind itself. Not to do so would be deny to the sanctity of "humanity". Current efforts by the international legal community to provide protection to animals, to criminalise foeticide, to clarify the moral implications of cloning and genetic engineering, to prosecute crimes against humanity, and to protect the rights of women and children are based upon a meaningful and coherently and consistently applied respect for the value of life. It would be unthinkable if the same desire for justice did not give rise to the establishment of the deliberative forum called for in this

deserves scholarly attention, ethical and moral concern, and governmental initiatives". Rumage also refers to the "masculinisation" of births in India, Bangladesh, and South Korea, where ultrasound and amniocentesis has made sex-selection abortion almost a standard medical procedure (Rumage 1996 Cal W Int'l L J 26). 
paper. 


\section{Bibliography}

\section{Alston 1990 Hum Rts $Q$}

Alston $\mathrm{P}$ "The Unborn Child and Abortion under the Draft Convention on the Right of the Child" 1990 Hum Rts Q 156-178

Araujo 2007 NCBQ

Araujo RJ "The UN Declaration on Human Cloning. A Survey and Assessment of the Debate" 2007 NCBQ 129-149

Callahan "Sanctity of Life Principle"

Callahan D "The Sanctity of Life Principle: A New Consensus" in Pojman LP (ed) Life and Death: $A$ Reader in Moral Problems $2^{\text {nd }}$ ed (Wadsworth Belmont 2000) 64-98

Clark $1993 N Y \cup L$ Rev

Clark AE "Abortion and the Pied Piper of Compromise" 1993 NY U L Rev 265329

Cohen "Minimalism About Human Rights"

Cohen J "Minimalism About Human Rights: The Most We Can Hope For?" in Ten CL (ed) Theories of Rights (Ashgate England 2006) 419-442

Collett 2008 SC L Rev

Collett TS "Judicial Modesty and Abortion" 2008 SC L Rev 701-734

Dworkin 1997 Ariz St L J

Dworkin R "In Praise of Theory" 1997 Ariz St L J 353-376

Eriksson Reproductive Freedom

Eriksson MK Reproductive Freedom - In the Context of International Human

Rights and Humanitarian Law (Martinus Nijhoff Leiden 2000)

Falk and Strauss "Deeper Challenges" 
Falk $R$ and Strauss A "The Deeper Challenges of Global Terrorism" in Weston $\mathrm{BH}$ et al (eds) International Law and World Order. A Problem-orientated Coursebook $4^{\text {th }}$ ed (Thomson West St Paul 2006) 1442-1444

Fenzel 2007 Focus

Fenzel B "Turning Morality into Legitimate Law" 2007 Focus 34-37

Flood 2007 NCBQ

Flood P "Is International Law on the Side of the Unborn Child?" 2007 NCBQ 73-96

Franck Fairness in International Law

Franck TM Fairness in International Law and Institutions (Clarendon Press Oxford 1995)

Freeman 2004 Hum Rts $Q$

Freeman M "The Problem of Secularism in Human Rights Theory" 2004 Hum Rts $Q 375-400$

Ghai 2000 Cardozo L Rev

Ghai $\mathrm{Y}$ "Universalism and Relativism: Human Rights as a Framework for Negotiating Interethnic Claims" 2000 Cardozo L Rev 1095-1140

Handler and Jack Ballentine's Law Dictionary

Handler JD and Jack G (eds) Ballentine's Law Dictionary (Lawyers Cooperative Publishing New York 1994)

Ibegbu Rights of the Unborn Child

lbegbu J Rights of the Unborn Child in International Law (Edwin Mellen Press Lewiston 2000)

Isasi and Annas 2003 Case W Res J Int'I L

Isasi RM and Annas GJ "Arbitrage, Bioethics, and Cloning: The ABCs of 
gestating a United Nations Cloning Convention" 2003 Case W Res J Int'l L 397-414

Jarrell 2006 Ga J Int'l \& Comp L

Jarrell C "No worldwide consensus: The United Nations Declaration on Human Cloning" 2006 Ga J Int'l \& Comp L 205-232

Jarvie Rationality and Relativism

Jarvie IC Rationality and Relativism: In Search of a Philosophy and History of Anthropology (Routledge and Kegal Paul London 1984)

Jenks 1954 BYIL

Jenks CW "The Scope of International Law" 1954 BYIL 1-48

Joseph Human Rights and the Unborn Child

Joseph R Human Rights and the Unborn Child (Martinus Nijhoff Leiden 2009)

Klasing 1995 Pepp L Rev

Klasing MS "The death of an Unborn Child: Jurisprudential Inconsistencies in Wrongful Death, Criminal Homicide and Abortion Cases" 1995 Pepp L Rev 933-979

Lipkin 1991 Tul L Rev

Lipkin RJ "Kibitzers, Fuzzies, and Apes without Tails: Pragmatism and the Art of Conversation in Legal Theory" 1991 Tul L Rev69-140

Macedo 1990 Political Theory

Macedo S "The Politics of Justification" 1990 Political Theory 280-304

Magnuson and Lederman 2007 Wm Mitchell L Rev

Magnuson RJ and Lederman JM "Aristotle, Abortion and Fetal Rights" 2007 Wm Mitchell L Rev 767-786

Mason Troubled Pregnancy

Mason JK The Troubled Pregnancy: Legal Wrongs and Rights in 
Reproduction (Cambridge University Press New York 2007)

Michelman 1989 Fla L Rev

Michelman FI "Conceptions of Democracy in American Constitutional Argument: Voting Rights" 1989 Fla L Rev 443-490

Milligan 2007 Baylor U L Rev

Milligan LM "A Theory of Stability: John Rawls, Fetal Homicide, and Substantive Due Process" 2007 Baylor U L Rev 1177-1230

Montefiore "Neutrality, Indifference and Detachment"

Montefiore A "Neutrality, Indifference and Detachment" in Montefiore A and Graham A (eds) Neutrality and Impartiality: The University and Political Commitment (Cambridge University Press London 1975) 17-29

Mower Convention on the Rights of the Child

Mower GA The Convention on the Rights of the Child: International Law Support for Children (Greenwood Press Westport Connecticut 1997)

Nagel 1987 Philosophy and Public Affairs

Nagel T "Moral Conflict and Political Legitimacy" 1987 Philosophy and Public Affairs 215-240

O'Neill 2000 Political Studies

O'Neill S "The Politics of Inclusive Agreements: Towards a Critical Discourse Theory of Democracy" 2000 Political Studies 503-521

Packer Right to Reproductive Choice

Packer CAA The Right to Reproductive Choice - A Study in International Law (Ábo Akademi University Finland 1996)

Parness 1985 Harv J Leg

Parness JA "Crimes against the Unborn: Protecting and Respecting the Potentiality of Human Life" 1985 Harv J Leg 97-172 
Paul 1995 Harv Int'l L J

Paul JCN "The United Nations and the Creation of an International Law of

Development" 1995 Harv Int'l L J 307-328

Petersen 2005 ZAÖRV

Petersen N "The Legal Status of the Human Embryo in vitro: General Human Rights Instruments" 2005 ZAÖRV 447-466

Rescher Pluralism

Rescher N Pluralism. Against the Demand for Consensus (Clarendon Press Oxford 1993)

Ritter 1997 Cal W Int'I L J

Ritter M "'Human Rights': Would you recognize one if you saw one? A Philosophical Hearing of International Rights Talk" 1997 Cal W Int'l L J 265310

Rubin Ethics and Authority

Rubin AP Ethics and Authority in International Law (Cambridge University Press United Kingdom 1997)

Rumage 1996 Cal W Int'I L J

Rumage SA "Resisting the West: The Clinton Administration's Promotion of Abortion at the 1994 Cairo Conference and the Strength of the Islamic Response" 1996 Cal W Int'l L J 1-100

Shanin 2002 Chicago J Int'l L

Shanin EL "International Response to Human Cloning" 2002 Chicago J Int'l L 255-262

Siegel 2008 Yale $L J$

Siegel "Dignity and the Politics of Protection: Abortion Restrictions under Casey/Carhart" 2008 Yale L J 1694-1801 
Slabbert 1999 CILSA

Slabbert MN "The Position of the Human Embryo and Foetus in International Law and its Relevance for the South African Context" 1999 CILSA 336-353

Sloane 2001 Vanderbilt J Transnat'l L

Sloane RD "Outrelativizing Relativism: A Liberal Defense of the Universality of International Human Rights" 2001 Vanderbilt J Transnat'I L 527-596

Sloth-Nielsen 1995 SAJHR

Sloth-Nielsen $J$ "Ratification of the United Nations Convention on the Rights of the Child: Some implications for South African law" 1995 SAJHR 401-420

Somerville "Birth, Death and Technoscience"

Somerville M "Birth, Death, and Technoscience. Searching for Values at the Margins of Life" in Farrow D (ed) Recognizing Religion in a Secular Society. Essays in Pluralism, Religion, and Public Policy (McGill-Queen's University Press Montreal 2004) 99-115

Sorrell 2003 Tulsa J Comp \& Int'l L

Sorrell K "Cultural Pluralism and International Rights" 2003 Tulsa J Comp \& Int'I L 369-418

Steinberg 1989 AJLM

Steinberg TN "Abortion Counseling: To Benefit Maternal Health" 1989 AJLM 483-518

Taylor "World Consensus"

Taylor C "A World Consensus on Human Rights?" in Ten CL (ed) Theories of Rights (Ashgate England 2006) 411-417

Tomuschat 1999 Recueil Des Cours

Tomuschat $C$ "International law: ensuring the survival of mankind on the eve of a new century: general course on public international law" 1999 Recueil Des Cours 9-438 
Tsao 1998 Hastings Const $L Q$

Tsao A "Feticide Homicide Laws: Shield against domestic violence or sword to pierce abortion rights?" 1998 Hastings Const L Q 457-481

Von Bogdandy 2006 Harv Int'l L J

Von Bogdandy A "Constitutionalism in International Law: Comment on a Proposal from Germany" 2006 Harv Int'l L J 223-243

Warren Moral Status

Warren MA Moral Status: Obligations to Persons and Other Living Things (Clarendon Press Oxford 1997)

Watt "Giving unto Caesar"

Watt G "Giving unto Caesar: Rationality, Reciprocity, and Legal Recognition of Religion" in O'Dair R and Lewis A (eds) Law and Religion, Current Legal Issues Vol 4 (Oxford University Press Oxford 2001) 45-64

Wilkins and Reynolds 2006 Ave Maria $L J$

Wilkins RG and Reynolds J "International Law and the Right to Life" 2006 Ave Maria L J 123-169

\section{Register of cases}

Roe $v$ Wade 410 US 113 (1973)

SA Commercial Catering and Allied Workers Union v Irvin and Johnson Ltd (Seafood Division Fish Processing) 20008 BCLR 886 (CC)

\section{Register of official documents}

African Charter on Human and Peoples' Rights (1986)

European Convention for the Protection of Human Rights and Fundamental Freedoms (1950)

Convention on the Rights of the Child (1989) 
International Covenant on Civil and Political Rights (1966)

Protocol to the African Charter on Human and Peoples' Rights on the Rights of Women in Africa (2003)

United Nations Charter (1945)

United Nations Convention on the Elimination of All Forms of Discrimination Against Women (1979)

United Nations Declaration on Human Cloning (2005) 


\section{Register of internet sources}

Araujo (year unknown) www.fww.org

Araujo RJ (year unknown) What is Family; Who is a Person? Questions for International Law www.fww.org/articles/wfpforum/raraujo.htm [date of use 16 Jul 2010]

European Union (date unknown) eur-lex.europa.eu

European Union (date unknown) Protocol of the Treaty of Amsterdam Amending the Treaty on European Union eurlex.europa.eu/en/treaties/dat/11997D/htm/11997D.html\#0110010013 [date of use $16 \mathrm{Ju} 2010]$

Georgetown Law Library (year unknown) www.ll.georgetown.edu

Georgetown Law Library (year unknown) International and Foreign Animal Law Research Guide: Animal Law Worldwide www.Il.georgetown.edu/int/guides/InternationalAnimalLaw.cfm [date of use 4 Feb 2010]

Michigan State University College of Law: Animal Legal and Historical Centre (year unknown) www.animallaw.info

Michigan State University College of Law: Animal Legal and Historical Centre (year unknown) Proposed Convention on the Protection of Animals www.animallaw.info/treaties/itconfprotanimal.htm [date of use $16 \mathrm{Jul} 2010$ ]

Our Dogs Shop (year unknown) www.ourdogs.co.uk

Our Dogs Shop (year unknown) Declaration for Animal Welfare 'on UN Agenda' www.ourdogs.co.uk/News/2006/December2006/291206/un.htm [date of use 4 Feb 2010]

Pregnantpause (year unknown) www.pregnantpause.org

Pregnantpause (year unknown) Summary of Abortion Laws Around the World www.pregnantpause.org/lex/world02.jsp [date of use 4 Feb 2010]

Smith 2008 www.aul.org 
Smith RM 2008 Informed Consent Laws: Protecting a Woman's Right to Know www.aul.org [date of use 15 Mar 2010]

Uncaged (year unknown) www.uncaged.co.uk

Uncaged (year unknown) Universal Declaration of Animal Rights www.uncaged.co.uk/declarat.htm [date of use 4 Feb 2010]

\section{List of abbreviations}

AJLM

Ariz St L J

Ave Maria L J

Baylor U L Rev

BYIL

Cal W Int'I L J

Cardozo L Rev

Case W Res J Int'I L

Chicago J Int'l L

CILSA

CRC

DRC

Fla L Rev

Ga J Int'I \& Comp L

Harv Int'l L J

Harv J Leg

Hastings Const $L \mathrm{Q}$

Hum Rts Q

ICC

ICCPR

NCBQ

$N Y \cup L \operatorname{Rev}$
American Journal of Law and Medicine

Arizona State Law Journal

Ave Maria Law Journal

Baylor University Law Review

British Yearbook of International Law

California Western International Law Journal

Cardozo Law Review

Case Western Reserve Journal of International Law

Chicago Journal of International Law

Comparative and International Law Journal of

Southern Africa

Convention on the Rights of the Child

Declaration on the Rights of the Child

Florida Law Review

Georgia Journal of International and Comparative Law

Harvard International Law Journal

Harvard Journal on Legislation

Hastings Constitutional Law Quarterly

Human Rights Quarterly

International Criminal Court

International Covenant on Civil and Political Rights

National Catholic Bioethics Quarterly

New York University Law Review 
Pepp L Rev Pepperdine Law Review

SAJHR

South African Journal on Human Rights

SC L Rev

South Carolina Law Review

Tul L Rev

Tulane Law Review

Tulsa J Comp \& Int'l L Tulsa Journal of Comparative and International Law

UDHR

Universal Declaration of Human Rights

UN

United Nations

Vanderbilt J Transnat'I L Vanderbilt Journal of Transnational Law

Wm Mitchell L Rev

William Mitchell Law Review

Yale L J

Yale Law Journal 